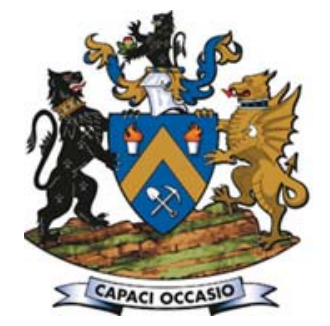

\title{
Selection of an appropriate leaching method for light REEs from Esfordi flotation concentrate based on mineral characterization
}

\author{
by F. Soltani*, M. Abdollahy* *, S.M. Javad Koleini*, and \\ D. Moradkhani ${ }^{\dagger}$
}

\section{Synopsis}

The objective of the study was to determine the type and distribution of rare earth elements (REEs) in the phosphate flotation concentrate from the Esfordi flotation plant in central Iran, in order to understand their leaching behaviour. Samples of the concentrate were prepared and analysed using XRF, XRD, ICP, and EMPA. The Ce, $\mathrm{Nd}$, $\mathrm{La}$, and $\mathrm{Y}$ contents were $5608,2227,1959$, and $679.7 \mathrm{mg} / \mathrm{kg}$, respectively. The main REEbearing minerals in the concentrate are fluorapatite, monazite, and xenotime. Apatite is the chief mineral of the concentrate and the ratio of apatite to monazite is greater than 60. From EMPA analysis, monazite contains a much higher proportion of REEs than apatite, but more than $50 \%$ of the REE content of the concentrate is in apatite, as this is the main mineral constituent of the concentrate. During the leaching of REEs in the phosphoric acid production process, more than $99 \%$ of the total rare earth values report to the large amounts of phosphogypsum $\left(\mathrm{CaSO}_{4} \cdot 2 \mathrm{H}_{2} \mathrm{O}\right)$ formed during the dissolution reaction. Accordingly, two process options are suggested for treating the Esfordi concentrate. In the first option, the concentrate is treated with $98 \% \mathrm{H}_{2} \mathrm{SO}_{4}$ at $200-300^{\circ} \mathrm{C}$. After digestion and water leaching, phosphorus and REEs are precipitated out of solution. In the second option, the concentrate is treated in a pre-leach stage. The process residue from the pre-leach stage is then subjected to acid digestion at elevated temperature for phosphoric acid production.

Keywords

Esfordi phosphate, mineral characterization, rare earth elements, leaching.

\section{Introduction}

The rare earth elements (REEs) comprise a set of 17 chemical elements in the periodic table, specifically the 15 lanthanides plus scandium and yttrium. REEs and alloys that contain them are used in devices such as computer memory, rechargeable batteries, cell phones, catalytic converters, magnets, fluorescent lighting, and many more (Krishnamurthy and Gupta, 2004). China supplies about $94 \%$ of the REE demand, with the remaining 6\% coming from Russia and Estonia, the USA, India, Malaysia, and Brazil (Zhanheng, 2011). Increased industrial development in China has prompted the Chinese government to limit annual export quotas to approximately $35 \mathrm{kt}$ of rare earth oxides (REOS), while non-Chinese annual demand is expected to reach $80 \mathrm{kt}$ by the year 2015. This constriction of supply is being met by the development of many new rare earth mining projects, each of which has its own unique mining and processing challenges (Jordens, Cheng, and Waters, 2013). One of these projects is the Esfordi phosphate project, which is located in Yazd Province in central Iran. The concentrate from the Esfordi flotation plant contains $1.2-1.5 \%$ REEs.

The REEs occur in over 160 discrete minerals. Most of these minerals are rare but the REE contents, expressed as oxide, can be as high as $60 \%$ REOs. Among these, bastnasite ((Ce,La) $\left.\mathrm{FCO}_{3}\right)$ occurs most frequently, monazite ((Ce,La, $\left.\mathrm{Nd}, \mathrm{Th}, \mathrm{U}, \ldots) \mathrm{PO}_{4}\right)$ is second, and xenotime $\left(\mathrm{YPO}_{4}\right)$ is the distant third. Other rare earth minerals that have been or are now used as REE resources include apatite, brannerite, euxenite, gadolinite, loparite, and uraninite. Allanite, apatite, and other phosphorite sources, eudialyte, fergusonite, floreneite, parisite, perovskite, pyrochlore, zircon, and a few other naturally occurring rare-earth-bearing materials are also considered potential rare earth resources (Krishnamurthy and Gupta, 2004). Ion adsorption clays containing about 0.05-0.2 wt.\% REOs are another group of REE deposits (Moldoveanu and Papangelakis, 2012). The general formula for apatite is $\mathrm{Ca}_{5}\left(\mathrm{PO}_{4}\right)_{3} \mathrm{X}$, where $\mathrm{X}$ is a fluoride or chloride ion or a hydroxyl group. Apatite, containing an average of $0.1-0.8 \%$ REOs, is the main source of phosphate fertilizers and phosphoric acid (Krishnamurthy and Gupta, 2004). The mode of occurrence and distribution of the rare-earth minerals in phosphate concentrates has generally ensured that they could be recovered only as by-products or co-products. Chemical beneficiation or chemical processing of the concentrate obtained after physical beneficiation usually involves hydrometallurgical, and sometimes pyrometallurgical, operations (Krishnamurthy and Gupta, 2004).

\footnotetext{
* Department of Mining Engineering, Tarbiat Modares University, Tehran, Iran.

+ Department of Mining Engineering, University of Zanjan, Zanjan, Iran.

¥* Corresponding Author.

(C) The Southern African Institute of Mining and Metallurgy, 2017. ISSN 2225-6253. Paper received Jun. 2016; revised paper received Oct. 2016.
} 


\section{Selection of an appropriate leaching method for light REEs}

The Esfordi deposit is the most REE-rich and P-rich member of the iron deposits in the Bafgh (Yazd Province) district. In the Esfordi plant (Figure 1), flotation is used to recover apatite from the ore. Numerous minerals occur intimately intergrown in the rare-earth-bearing Esfordi phosphate ore. The objective of the present study is to determine the type and distribution of REEs in the products of the Esfordi flotation plant in order to predict their behaviour during leaching REEs. In this regard, the leaching behaviour of the Esfordi flotation concentrate in the wet process for phosphoric acid production was investigated and compared to leaching with $\mathrm{HNO}_{3}$ and $\mathrm{HCl}$.

\section{Experimental}

\section{Esfordi flotation concentrate}

The Esfordi plant is situated $35 \mathrm{~km}$ northeast of Bafgh, Yazd Province, in central Iran. Samples containing 1.2-1.5\% REEs were obtained from the Esfordi flotation plant. Sub-samples, with a size distribution of $80 \mathrm{wt} . \%<54 \mu \mathrm{m}$, were used for the characterization and leaching studies without any further size reduction. Optical mineralogy using polished and thin sections, semi-quantitative X-ray diffraction (SQXRD), X-ray fluorescence (XRF), inductively coupled plasma (ICP), scanning electron microscopy with wavelength dispersive spectroscopy (SEM-WDX), and electron microprobe analysis (EMPA) techniques were applied for ore characterization. The elemental analysis of the concentrate sample is shown in Table I. XRD analysis (Figure 2) showed that fluorapatite, magnetite, montmorillonite, calcite, talc, quartz, and haematite are present in the Esfordi concentrate. As shown in Figure 2, the iron ore minerals are magnetite and haematite.

More than 25 different elements have been reported to occur in fluorapatite. At Esfordi, chlorine, fluorine, iron, calcium, and the REEs are of particular importance if the concentrate is to be used for the production of phosphoric acid..

Quantitative analysis of the apatite and monazite minerals was carried out using a Superprobe Jeol JXA8100 microprobe at the Geology Department, University of Cape Town.

\section{Leaching experiments}

High-purity deionized water and analytical-grade acids were used throughout all experiments. The leaching experiments simulating the conventional wet process were performed in a stirred 1-litre glass reactor immersed in a thermostatically controlled water bath. A total of $500 \mathrm{~mL}$ of the leaching solution was prepared using reagent-grade phosphoric/sulphuric acid and deionized water. $100 \mathrm{~g}$ of

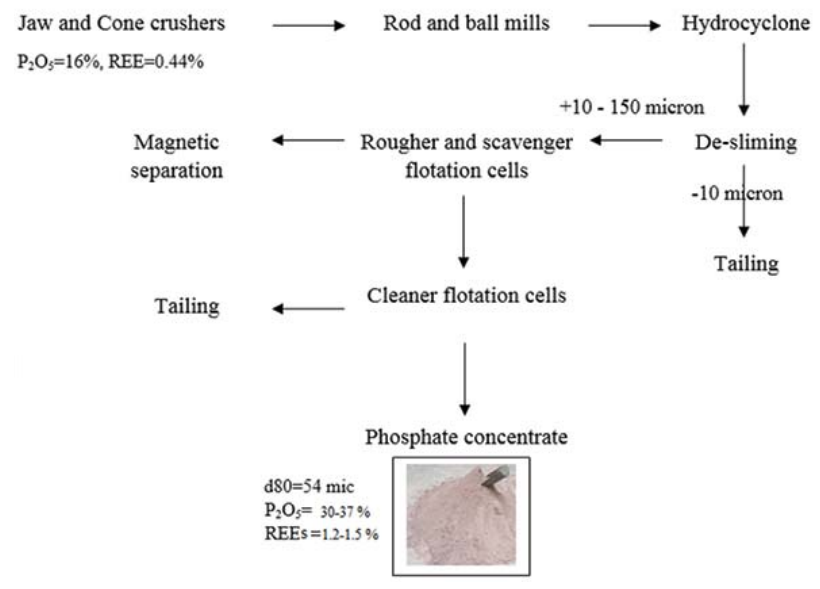

Figure 1-Main unit operations of the Esfordi flotation plant

\begin{tabular}{|c|c|c|c|c|c|}
\hline \multicolumn{6}{|l|}{ Table I } \\
\hline \multicolumn{6}{|c|}{ Elemental analysis of the concentrate sample } \\
\hline \multicolumn{2}{|c|}{ Major elements } & \multicolumn{2}{|c|}{ Minor elements } & \multicolumn{2}{|c|}{ Rare earths } \\
\hline Element & Mass $\%$ & Element & ppm (mg/kg) & Element & ppm (mg/kg) \\
\hline $\begin{array}{l}\mathrm{Ca} \\
\mathrm{P} \\
\mathrm{Fe} \\
\mathrm{F} \\
\mathrm{Cl}\end{array}$ & $\begin{array}{c}37.13 \\
14.04 \\
2.91 \\
3.00 \\
0.33\end{array}$ & $\begin{array}{c}\mathrm{Si} \\
\mathrm{Mg} \\
\mathrm{Na} \\
\mathrm{Al} \\
\mathrm{S} \\
\mathrm{Sr} \\
\mathrm{Ti} \\
\mathrm{K} \\
\mathrm{V} \\
\mathrm{Mn} \\
\mathrm{Th} \\
\mathrm{U}\end{array}$ & $\begin{array}{c}7500 \\
2055 \\
1476 \\
1127 \\
692 \\
333.8 \\
213 \\
220 \\
123 \\
88 \\
82.48 \\
4.6\end{array}$ & $\begin{array}{l}\mathrm{Ce} \\
\mathrm{Nd} \\
\mathrm{La} \\
\mathrm{Y} \\
\mathrm{Pr} \\
\mathrm{Sm} \\
\mathrm{Dy} \\
\mathrm{Er} \\
\mathrm{Eu} \\
\mathrm{Lu} \\
\mathrm{Tb} \\
\mathrm{Yb} \\
\mathrm{Gd}\end{array}$ & $\begin{array}{c}5608 \\
2227 \\
1959 \\
679.7 \\
614.05 \\
342.85 \\
154.05 \\
129.77 \\
29.4 \\
4.26 \\
42.6 \\
31.7 \\
188.07\end{array}$ \\
\hline
\end{tabular}

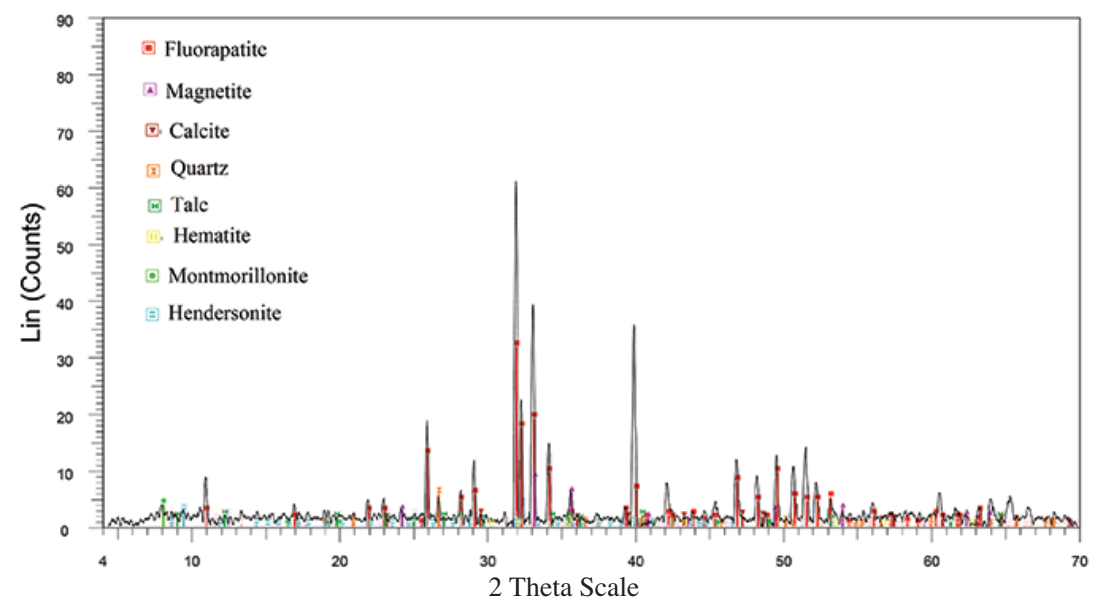

Figure 2-XRD analysis of the Esfordi flotation concentrate 


\section{Selection of an appropriate leaching method for light REEs}

apatite concentrate was added to the leaching solution when the temperature reached the pre-set value $\left(80^{\circ} \mathrm{C}\right)$. The $\mathrm{pH}$, redox potential, and elemental concentrations in the leach solution were measured regularly. After completion of the leaching experiment (3 hours for leaching-precipitation), the pulp was filtered, and the solid residue was washed three times with $5 \%$ phosphoric acid, and dried to a constant weight. The $\mathrm{HNO}_{3}$ and $\mathrm{HCl}$ leaching experiments were conducted at $30 \%$ (w/w) solids with $500 \mathrm{~mL}$ of each acid at the desired concentrations. The rotation speed of the agitator was maintained at $500 \mathrm{r} / \mathrm{min}$ for all experiments.

The pregnant leach solution and wash solutions were combined for assay. All the solid and liquid samples were analysed to provide data to calculate the mass balance and leaching efficiency. The redox potential was monitored using a Metrohm $827 \mathrm{Lab}$ unit with an $\mathrm{Ag} / \mathrm{AgCl}$ reference electrode. $\mathrm{Ca}, \mathrm{Fe}$, and REEs were determined by ICP (induced coupled plasma). $\mathrm{P}$ was analysed by spectrophotometry.

\section{Results and discussion}

\section{Genesis of the Esfordi phosphate ore}

The representative results of EMPA analysis for apatite and monazite are presented in Table II. Results for apatite and monazite grains in the flotation concentrate samples were close to those reported for original feed samples (Booomeri,
2011). As can be seen from Table II, the main phosphate mineral in the Esfordi ore is essentially fluorapatite. Apatite samples have $\mathrm{F}$ and $\mathrm{Cl}$ ranges of $3.12-5.27$ wt.\% and 0.351.34 wt.\%, respectively, and contain low values of Fe and Si. Quartz is the main source of Si in the concentrate (Figure 2). It was not possible to analyse the composition of fine xenotime particles by EMPA.

The deposit is regarded as being intrusive in origin. All the Esfordi ore types show evidence of a complex cooling history, involving processes such as primary igneous crystallization (formation of clinopyroxene, andradite, apatite, and massive magnetite), followed by infiltration by late silica-, carbonate-, and iron-bearing fluids (formation of actinolite, chlorite, epidote, and calcite-quartz veins). Subsequent hydrothermal infill formed monazite and allanite inclusions in apatite grains. First-stage fluids depleted apatite in $\mathrm{Na}$ and $\mathrm{Si}$ and formed monazite-allanite minerals as inclusion within apatite grains (Booomeri, 2011; Bonyadi et al., 2011).

\section{Rare earth minerals in the Esfordi phosphate ore}

As can be seen from Figure 3, light REEs (lanthanum, cerium, and neodymium) and the heavy REE Y are the most prominent in the concentrate. The total REE content in the concentrate is $1.20 \%$. The concentrate contains $5608 \mathrm{mg} / \mathrm{kg}$ Ce, $1959 \mathrm{mg} / \mathrm{kg} \mathrm{La}, 2227 \mathrm{mg} / \mathrm{kg} \mathrm{Nd}$, and $679.7 \mathrm{mg} / \mathrm{kg} \mathrm{Y}$. As can be seen from Figure 3, the light and heavy REEs total 1.10 and $0.1 \mathrm{wt} . \%$, respectively.

Table II

Selected major and minor element concentrations (wt.\%) in apatite and monazite minerals (WDS-EMPA data

\begin{tabular}{|c|c|c|c|c|c|c|c|c|c|c|c|}
\hline \multicolumn{2}{|l|}{ Mineral } & $\mathrm{SiO}_{2}$ & $\mathrm{P}_{2} \mathrm{O}_{5}$ & $\mathrm{CaO}$ & $\mathrm{La}_{2} \mathrm{O}_{3}$ & $\mathrm{Y}_{2} \mathrm{O}_{3}$ & $\mathrm{Cl}$ & $\mathrm{Ce}_{2} \mathrm{O}_{3}$ & $\mathbf{F}$ & $\mathrm{Nd}_{2} \mathrm{O}_{3}$ & $\mathrm{FeO}$ \\
\hline Apatite & $\begin{array}{c}1 \\
2 \\
3 \\
4 \\
5 \\
6 \\
7 \\
8 \\
9 \\
10\end{array}$ & $\begin{array}{l}0.07 \\
0.22 \\
0.16 \\
0.23 \\
0.16 \\
0.21 \\
0.26 \\
0.04 \\
0.07 \\
0.16\end{array}$ & $\begin{array}{l}41.69 \\
42.10 \\
43.08 \\
42.35 \\
42.99 \\
43.63 \\
41.92 \\
44.04 \\
44.26 \\
43.06\end{array}$ & $\begin{array}{l}55.21 \\
55.53 \\
55.54 \\
53.89 \\
54.85 \\
54.38 \\
53.63 \\
55.45 \\
55.09 \\
54.40\end{array}$ & $\begin{array}{l}0.18 \\
0.04 \\
0.23 \\
0.24 \\
0.20 \\
0.22 \\
0.31 \\
0.10 \\
0.14 \\
0.25\end{array}$ & $\begin{array}{l}0.19 \\
0.14 \\
0.11 \\
0.54 \\
0.17 \\
0.14 \\
0.10 \\
0.03 \\
0.06 \\
0.13\end{array}$ & $\begin{array}{l}0.58 \\
0.35 \\
0.66 \\
1.32 \\
0.73 \\
1.05 \\
1.34 \\
0.50 \\
0.58 \\
0.84\end{array}$ & $\begin{array}{l}0.47 \\
0.23 \\
0.64 \\
0.77 \\
0.64 \\
0.48 \\
0.90 \\
0.29 \\
0.33 \\
0.64\end{array}$ & $\begin{array}{l}3.48 \\
5.27 \\
3.67 \\
3.12 \\
2.66 \\
3.40 \\
4.22 \\
4.77 \\
4.08 \\
3.18\end{array}$ & $\begin{array}{l}0.19 \\
0.16 \\
0.24 \\
0.33 \\
0.24 \\
0.26 \\
0.37 \\
0.11 \\
0.14 \\
0.27\end{array}$ & $\begin{array}{l}0.07 \\
0.04 \\
0.07 \\
0.10 \\
0.10 \\
0.07 \\
0.10 \\
0.06 \\
0.08 \\
0.07\end{array}$ \\
\hline & & $\mathrm{SiO}_{2}$ & $\mathrm{P}_{2} \mathrm{O}_{5}$ & $\mathrm{CaO}$ & $\mathrm{La}_{2} \mathrm{O}_{3}$ & $\mathrm{Y}_{2} \mathrm{O}_{3}$ & $\mathrm{Cl}$ & $\mathrm{Ce}_{2} \mathrm{O}_{3}$ & $\mathbf{F}$ & $\mathrm{Nd}_{2} \mathrm{O}_{3}$ & $\mathrm{FeO}$ \\
\hline Monazite & $\begin{array}{l}1 \\
2 \\
3 \\
4 \\
5 \\
6\end{array}$ & $\begin{array}{l}0.06 \\
0.09 \\
0.17 \\
0.17 \\
0.41 \\
0.03\end{array}$ & $\begin{array}{l}33.49 \\
33.95 \\
32.91 \\
32.91 \\
30.66 \\
28.05\end{array}$ & $\begin{array}{l}0.84 \\
0.91 \\
0.77 \\
0.77 \\
0.33 \\
0.61\end{array}$ & $\begin{array}{l}13.45 \\
13.48 \\
11.80 \\
11.80 \\
11.76 \\
11.89\end{array}$ & $\begin{array}{l}0.93 \\
1.03 \\
0.16 \\
0.16 \\
0.53 \\
0.26\end{array}$ & $\begin{array}{l}0.19 \\
0.17 \\
0.23 \\
0.23 \\
0.20 \\
0.18\end{array}$ & $\begin{array}{l}35.01 \\
33.83 \\
33.83 \\
33.83 \\
34.55 \\
34.00\end{array}$ & $\begin{array}{l}0.77 \\
0.52 \\
0.61 \\
0.61 \\
0.79 \\
0.90\end{array}$ & $\begin{array}{l}10.37 \\
10.47 \\
12.80 \\
12.80 \\
12.75 \\
12.77\end{array}$ & $\begin{array}{l}- \\
- \\
- \\
- \\
- \\
-\end{array}$ \\
\hline
\end{tabular}
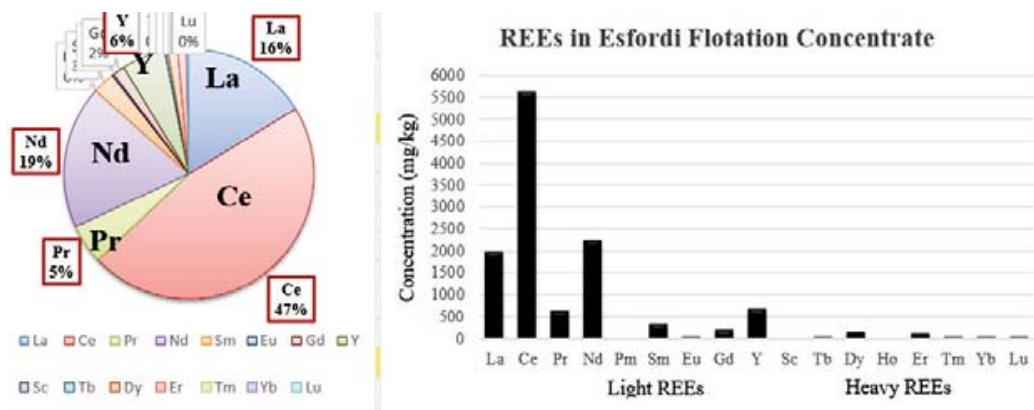

Figure 3-REE content in the Esfordi flotation concentrate 


\section{Selection of an appropriate leaching method for light REEs}

As leaching of REEs from the concentrate is strongly governed by the types and concentrations of the different mineral phases within the concentrate, a comparative evaluation of REE distribution in apatite and monazite minerals using EMPA was carried out. As shown in Figure 4, the REE minerals are closely associated with apatite and formed mainly in or around apatite grains and within veins and veinlets. The REE-bearing minerals are mainly phosphates. Monazite is highly enriched in light REEs such as Ce, $\mathrm{La}$, and $\mathrm{Nd}$. Xenotime is the main source of $\mathrm{Y}$ in the concentrate (Figure 4).

The fluid interaction introduced the silicate components responsible for the formation of allanite, talc, tremolite, chlorite, quartz, and carbonates along apatite grain boundaries (Boomeri, Nakashima, and Lentz, 2009). Allanite $\left((\mathrm{Ce}, \mathrm{Ca}, \mathrm{Y})_{2}\left(\mathrm{Al}, \mathrm{Fe}^{3+}\right)_{3} \mathrm{Si}_{3} \mathrm{O}_{12}(\mathrm{OH})\right)$ occurs in the Esfordi ore, but it was not observed in the flotation concentrate.

Boomeri (2011) found five groups of REE minerals in the Esfordi ore samples. These are apatite, monazite-xenotime, allanite, parisite-synchysite, and britholite. Apatite, monazite, and xenotime are the main REE minerals in the Esfordi flotation plant concentrate (Figure 4).

Values for $\mathrm{Ce}_{2} \mathrm{O}_{3}, \mathrm{La}_{2} \mathrm{O}_{3}$, and $\mathrm{Nd}_{2} \mathrm{O}_{3}$ cover a range of 0.23 $0.90,0.04-0.31$, and $0.110 .37 \mathrm{wt} . \%$, respectively, in the apatite grains, and 33.83-35.01, 11.76-13.48, and 10.3712.80 wt.\%, respectively, in the monazite grains (Table II). Monazite contains high $\mathrm{Ce}, \mathrm{La}$, and Nd values, but low $\mathrm{Y}$ (0.16-1.03 wt.\%). In all samples, the brighter internal areas of the apatite have significantly higher contents of REE than the dark areas (Figure 4).

Nucleation of monazite in apatite in an open system is shown in Figure 5. Monazite is one of the stable minerals in oxidative pre-treatment and leaching processes (Jorjani, Bagherieh, and Chelgani, 2011).

Mineral particle counts (Figure 6) were performed on BSE images with a manual microscope-based particle counting system. Results showed that the Esfordi phosphate concentrate contains more than $57 \%$ fluorapatite and about $1.5 \%$ monazite and xenotime. As shown in Table II, monazite has a higher REE content than apatite. However, the majority of the REEs are contained in apatite, since the ratio of apatite to monazite is greater than 60 .

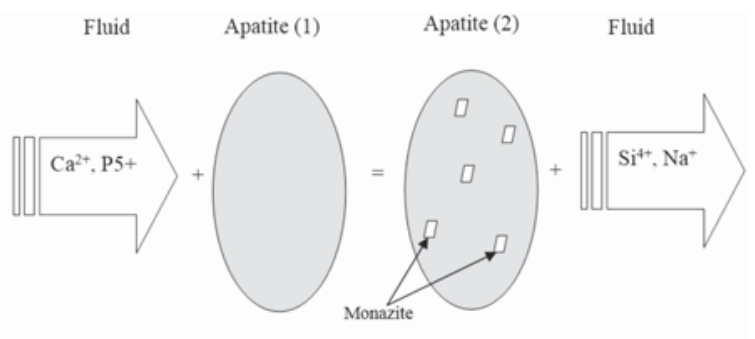

Apatite $(1)+\left(\mathrm{Ca}^{2+}, \mathrm{P}^{5+}\right)$ in a fluid $=$ apatite $(2)+$ monazite $+\left(\mathrm{Si}^{4+}, \mathrm{Na}^{+}\right)$in a fluid

Figure 5-Model for development of monazite inclusions in apatite (based on the reaction proposed by Boomeri, Nakashima, and Lentz, 2009)

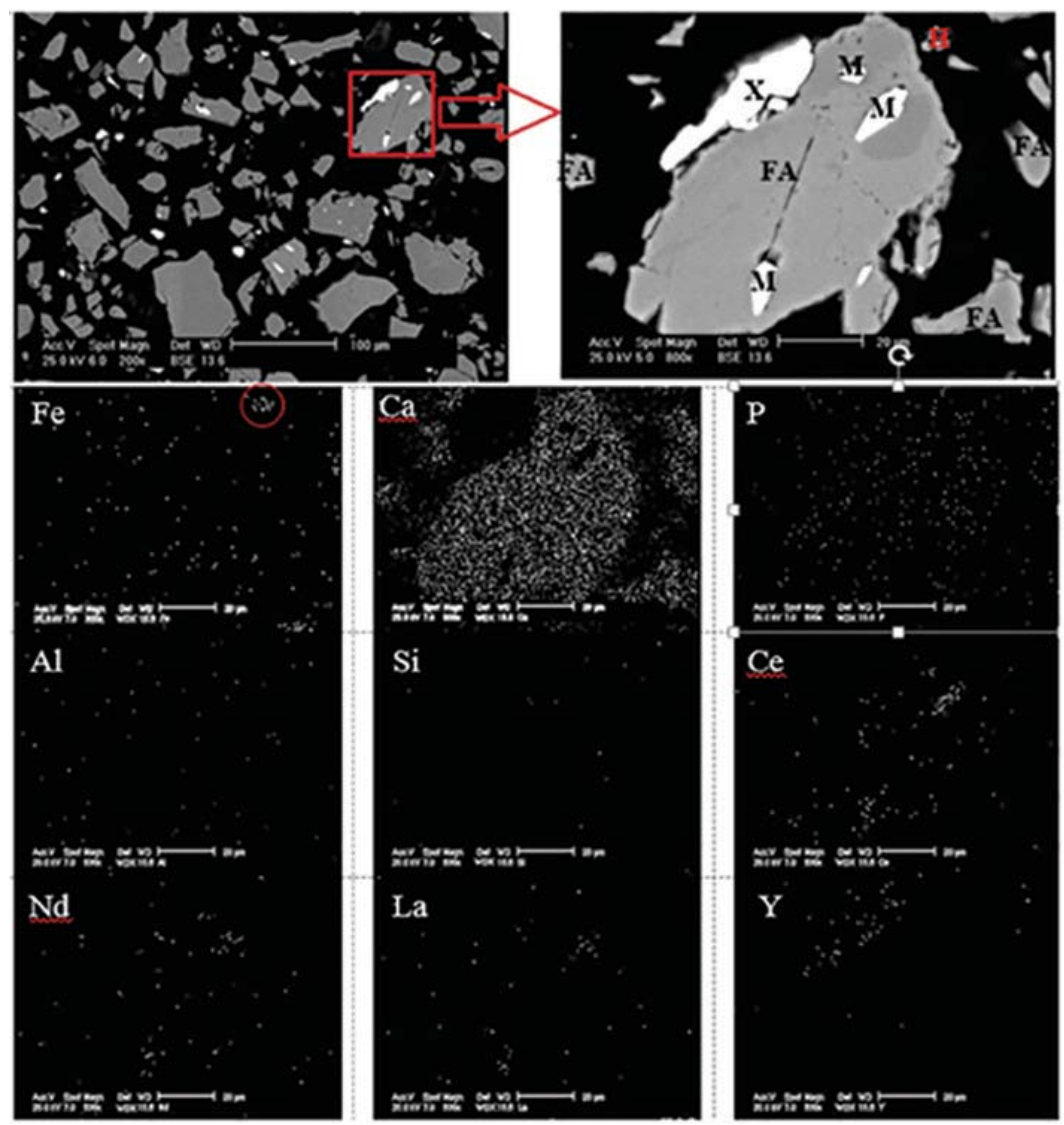

Figure 4-Backscattered electron image showing coarse apatite grains (grey) in the Esfordi flotation concentrate. White monazite (M) and xenotime (X) inclusions $(1-10 \mu \mathrm{m})$ are detected in the apatite grains 


\section{Selection of an appropriate leaching method for light REEs}

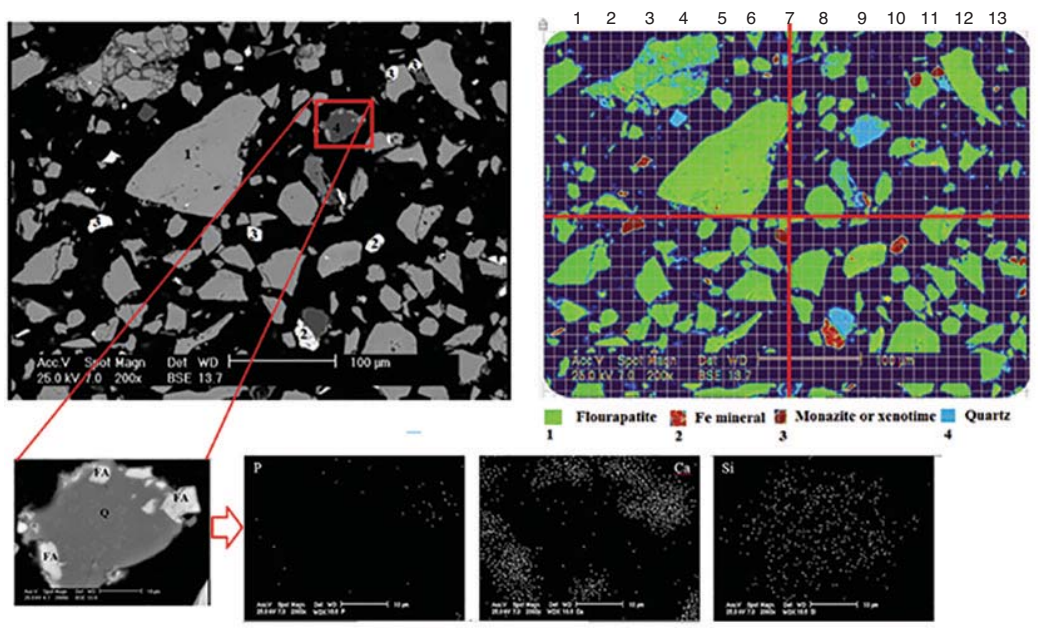

Figure 6-BSE high-contrast image of monazite-xenotime inclusion (4) in apatite (1), quartz, and Fe-minerals (200x and 2000x magnification)

\section{Leaching of concentrate samples}

\section{Chemical behaviour of REEs in the wet process for phosphoric acid production}

In the wet process for phosphoric acid production, phosphate rock is leached with a mixture of $\mathrm{H}_{2} \mathrm{SO}_{4}$ and $\mathrm{H}_{3} \mathrm{PO}_{4}$. The main reaction in the phosphoric acid production is as follows:

$$
\begin{aligned}
& \mathrm{Ca}_{10}\left(\mathrm{PO}_{4}\right)_{6} \mathrm{~F}_{2}+10 \mathrm{H}_{2} \mathrm{SO}_{4}+x \mathrm{H}_{2} \mathrm{O}=6 \mathrm{H}_{3} \mathrm{PO}_{4}+ \\
& 10 \mathrm{CaSO}_{4} \cdot \frac{x}{10} \mathrm{H}_{2} \mathrm{O} \downarrow+2 \mathrm{HF} \uparrow
\end{aligned}
$$

where $x=0$ for calcium sulphate anhydrate, $x=0.5$ for hemihydrate, and $x=2$ for dehydrate (Wang et al., 2010.

In the wet process leaching tests, concentrate samples were digested at $80^{\circ} \mathrm{C}$ by a mixture of concentrated sulphuric and phosphoric acids. A summary of the conditions of the leaching experiments at different acid concentrations and a solid-to-liquid ratio of 1: 5 is shown in Table III.

As shown in Table III, the leaching efficiency of REEs from the concentrate is only around $1 \%$. More than $99 \%$ of the total $\mathrm{RE}$ values end up in the large quantities of phosphogypsum $\left(\mathrm{CaSO}_{4} \cdot 2 \mathrm{H}_{2} \mathrm{O}\right)$ formed during the dissolution reaction (Table. III). This may be due either to monazite-xenotime not being attacked during leaching, or to encapsulation of REEs by the growth of phosphogypsum crystals during the crystallization process (Figure 7). It has been found that the lanthanides are present in isomorphous substitution with $\mathrm{Ca}^{2+}$ in the gypsum (Wang et al., 2010; Habashi, 1985).

$\mathrm{XRD}$ analysis of the white residue obtained from leaching of the apatite sample with $2 \mathrm{~mol} / \mathrm{L} \mathrm{H}_{2} \mathrm{SO}_{4}$ and $25 \% \mathrm{P}_{2} \mathrm{O}_{5}$ solution showed (Figure 8) that the residue consisted mainly of calcium sulphate dihydrate $\left(\mathrm{CaSO}_{4} \cdot 2 \mathrm{H}_{2} \mathrm{O}\right)$ and calcium sulphate hemihydrate $\left(\mathrm{CaSO}_{4} \cdot 0.5 \mathrm{H}_{2} \mathrm{O}\right)$. The mass ratio of residue to leaching feed was 1.28 . This indicates that the REE content in the solid residue is not enriched, but diluted. The amount of phosphogypsum produced in the wet process exceeds the mass of the target product, i.e. 4.5-5.5 $\mathrm{t}$ of phosphogypsum are generated per ton of phosphorus pentoxide (Binnemans et al., 2015).

\section{Leaching studies in $\mathrm{HNO}_{3}$ and $\mathrm{HCl}$}

The reaction of phosphate rock with $\mathrm{HNO}_{3}$ or $\mathrm{HCl}$ can be represented by Equations [2] and [3] (Habashi, 1985):

$$
\begin{aligned}
& \mathrm{Ca}_{10}\left(\mathrm{PO}_{4}\right)_{6} \mathrm{~F}_{2}+20 \mathrm{HNO}_{3}=6 \mathrm{H}_{3} \mathrm{PO}_{4}+10 \mathrm{Ca}\left(\mathrm{NO}_{3}\right)_{3}+2 \mathrm{HF} \\
& \mathrm{Ca}_{10}\left(\mathrm{PO}_{4}\right)_{6} \mathrm{~F}_{2}+20 \mathrm{HCl}=6 \mathrm{H}_{3} \mathrm{PO}_{4}+10 \mathrm{CaCl}_{2}+2 \mathrm{HF}
\end{aligned}
$$

When apatite is leached with $\mathrm{HNO}_{3}$ or $\mathrm{HCl}$, calcium does not precipitate due to high solubility of calcium nitrate and calcium chloride (Sandström and Fredriksson, 2012).

As shown in Table IV, leaching efficiencies of calcium and phosphate using $\mathrm{HCl}$ or $\mathrm{HNO}_{3}$ are close to $100 \%$. Unlike calcium and phosphate, REEs show a low leaching efficiency in either acid (Table. IV). This could be attributed to the complexation of REEs with fluoride (Krishnamurthy and Gupta, 2004; Khawassek et al., 2015). Monazite-xenotime is not attacked by $\mathrm{HNO}_{3}$ or $\mathrm{HCl}$ at low temperatures (Jordens, Cheng, and Waters, 2013). The behaviour of all four REEs in $\mathrm{HCl}$ is similar to that in $\mathrm{HNO}_{3}$.

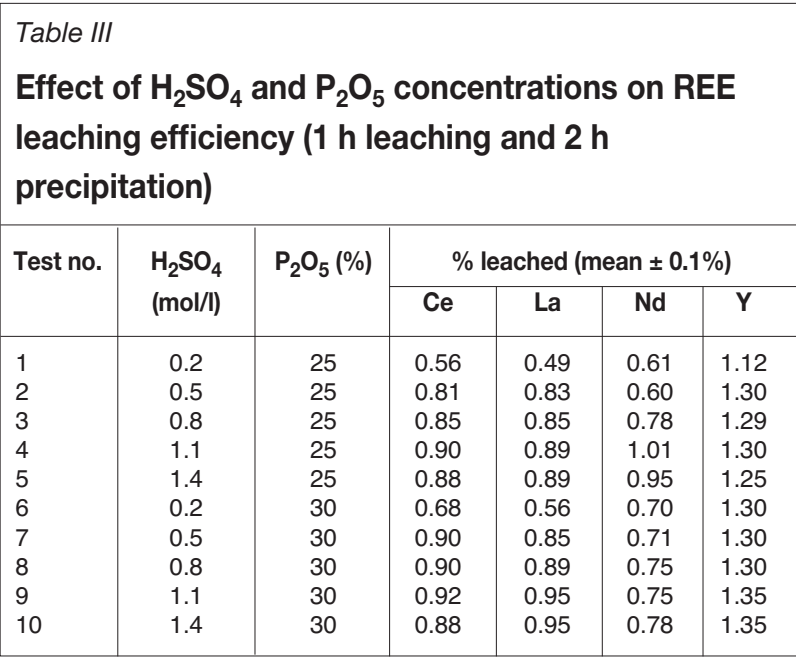


Selection of an appropriate leaching method for light REEs

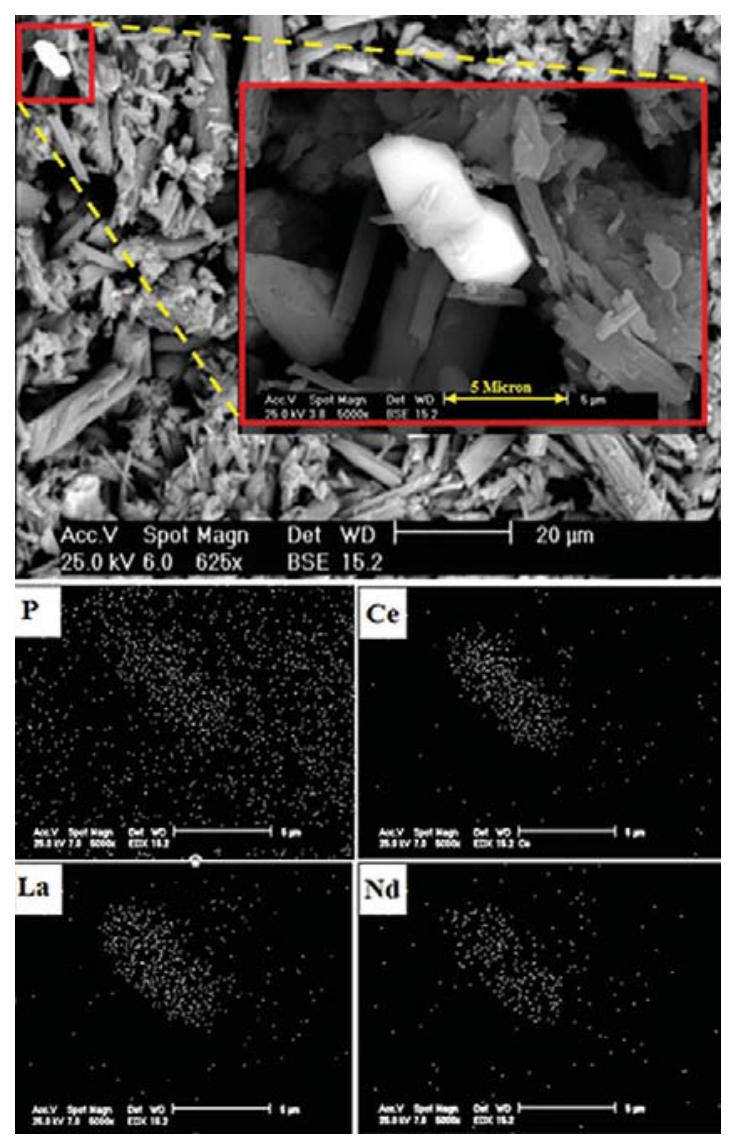

Figure 7-Backscattered electron image showing monazite grains (white) in the phosphogypsum residue (grey)
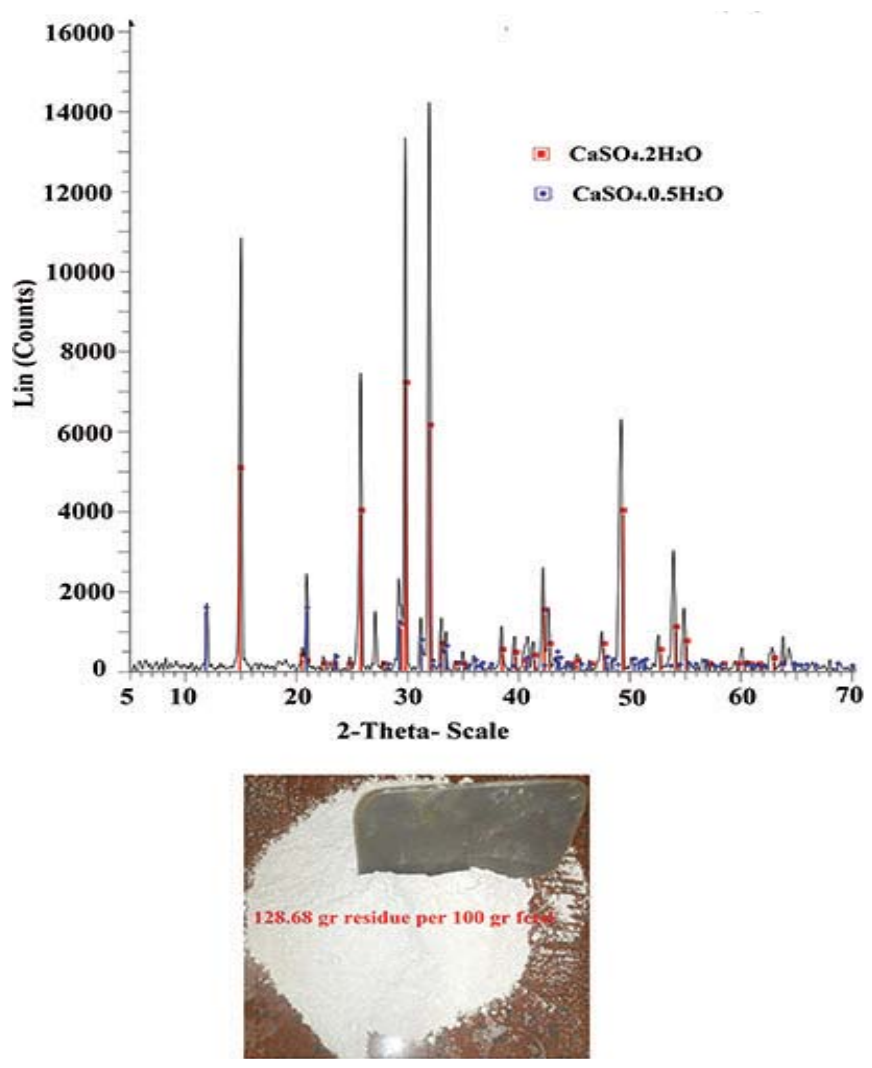

Figure 8-XRD analysis of the leach residue 


\section{Selection of an appropriate leaching method for light REEs}

\begin{tabular}{|c|c|c|c|c|c|c|c|c|c|c|c|}
\hline \multicolumn{12}{|c|}{ Table IV } \\
\hline \multicolumn{12}{|c|}{ Leaching efficiencies of calcium, phosphate, and REEs from concentrate samples in $\mathrm{HNO}_{3}$ and $\mathrm{HCl}$} \\
\hline \multirow[t]{2}{*}{ Acid } & \multirow[t]{2}{*}{ Concn (\%) } & \multirow[t]{2}{*}{ S/L (wt.\%) } & \multirow[t]{2}{*}{ Leaching time (h) } & \multirow[t]{2}{*}{$T\left({ }^{\circ} \mathrm{C}\right)$} & \multirow[t]{2}{*}{ Agitation (r/min) } & \multicolumn{6}{|c|}{ Leaching efficiency (\%) } \\
\hline & & & & & & $\mathrm{Ca}$ & $\mathbf{P}$ & $\mathrm{Ce}$ & La & Nd & $\mathbf{Y}$ \\
\hline HNO3 & 30 & 25 & 2 & 60 & 500 & 100 & 97.83 & 1.56 & 1.31 & 1.22 & 0.72 \\
\hline $\mathrm{HCl}$ & 20 & 25 & 2 & 60 & 500 & 100 & 98.11 & 1.48 & 1 & 1.32 & 0.56 \\
\hline
\end{tabular}

Leaching studies in $\mathrm{HNO}_{3}$ and $\mathrm{HCl}$ solutions showed that these acids can be used for selective leaching of calcium and phosphate from the concentrate.

\section{Selection of the appropriate leaching method}

\section{Chemical processing of monazite and xenotime}

Monazite should be digested at high temperatures as it is one of the most stable REE minerals. Monazite is decomposed using two main methods:

> Acid treatment-Baking with $98 \%$ sulphuric acid at temperatures ranging from $200-220^{\circ} \mathrm{C}$ (Equation [4]) is typically used (Krishnamurthy and Gupta, 2004; Abhilash, Meshram, and Pandey, 2016). With this method, depending on the acid/ore ratio, temperature, and concentration, either thorium or the REEs can be selectively solubilized or both thorium and REEs totally solubilized

> Alkali treatment - The reaction of rare earth phosphates with hot (about $\left.140^{\circ} \mathrm{C}\right)$, concentrated alkali (50-75\%) proceeds according to Equation [5] in 3-4 hours.

$$
2 \mathrm{REEPO}_{4}+3 \mathrm{H}_{2} \mathrm{SO}_{4}=\mathrm{REE}_{2}\left(\mathrm{SO}_{4}\right)_{3}+2 \mathrm{H}_{3} \mathrm{PO}_{4}
$$

$\mathrm{REEPO}_{4}+3 \mathrm{NaOH}=\mathrm{REE}(\mathrm{OH})_{3}+\mathrm{Na}_{3} \mathrm{PO}_{4}$

The hydroxide produced is treated using hot water (trisodium phosphate is soluble, whereas the REE hydroxides are not). The hydroxide precipitates are filtered off and subsequently leached with $\mathrm{HNO}_{3}$ or $\mathrm{HCl}$. The monazite alkali digestion method is useful for concentrates with REE grades of more than 30\% (Krishnamurthy and Gupta, 2004).

\section{Chemical processing of apatite}

As discussed, apatite is the main REE-bearing mineral of the Esfordi flotation concentrate as it is much more abundant than the other REE-bearing minerals. Thus, it is necessary to find an appropriate leaching route to extract REEs from the apatite.

Normally, apatite is the feed material to a wet-process phosphoric acid plant, where it is dissolved in a mixture of sulphuric acid and recycled dilute phosphoric acid. As mentioned, most of the rare earth values end up in the significant amounts of phosphogypsum formed in the dissolution reaction (Figures 7 and 8). Although various techniques to recover rare earths from the phosphogypsum have been developed, these are considered too complex and uneconomical to be industrialized (Wang et al., 2010).

\section{Proposed routes for processing the Esfordi concentrate}

Given the foregoing discussion, it seems that potential process options for treating the Esfordi phosphate concentrate to produce phosphoric acid and recover REEs are as follows.

> Acid bake of the concentrate. In the acid bake stage, the concentrate is treated with $98 \% \mathrm{H}_{2} \mathrm{SO}_{4}$ at $200-$ $300^{\circ} \mathrm{C}$. After cooling, the decomposition products are leached with water (Jha et al., 2016). It is assumed that the REE sulphates formed will dissolve with the phosphoric acid and not become associated with the $\mathrm{CaSO}_{4}$ residue. During acid dissolution, the phosphate ions are converted to a low-grade phosphoric acid which is not suitable for further upgrading by conventional methods (evaporation or solvent extraction). The phosphorus is then precipitated, for example by the addition of iron to the solution. Iron (III) phosphate can be used in steel and other metal manufacturing processes as it prevents oxidation of the metal. Iron phosphate coatings are also primarily used as base coatings for paint (Wikipedia, 2016). Finally, the REEs are converted to hydroxide with caustic soda (Li et al., 2009)

> Acid leaching of the concentrate with $\mathrm{HNO}_{3}, \mathrm{HCl}$, or $\mathrm{H}_{3} \mathrm{PO}_{4}$ to dissolve apatite prior to the acid digestion stage (Bandara and Senanayake, 2015). Hydrochloric acid could in principle be used, but is not in practice due to its high corrosivity. Dissolution in nitric acid is relatively common, with about 100 plants throughout the world producing complex fertilizers (Sandström and Fredriksson, 2012). Phosphoric acid is produced from the dissolved apatite, which still contains dissolved $\mathrm{Ca}$. The dissolved Ca could be precipitated as gypsum $\left(\mathrm{CaSO}_{4} \cdot 2 \mathrm{H}_{2} \mathrm{O}\right)$ by the addition of a stoichiometric amount of sulphuric acid (Stone et al., 2016). Process residue from the pre-leach stage is subjected to acid baking at elevated temperature.

\section{Conclusion}

The type and distribution of REE minerals in the phosphate concentrate of the Esfordi flotation plant play an important role in the selection of REE processing methods. Apatite is the main REE-bearing mineral in the concentrate, and the ratio of apatite to monazite is greater than 60 . However, apatite contains only $2 \%$ REE oxides, whereas the monazite phase contains around $45 \%$. Therefore meaningful recovery of REEs from this material needs to take both minerals into account.

Two options for treating the Esfordi concentrate are hence proposed:

> Acid digestion of the concentrate followed by water leaching and sequential precipitation of phosphorus and REEs

> Acid leaching of the concentrate with $\mathrm{HNO}_{3}$ or $\mathrm{HCl}$ to 


\section{Selection of an appropriate leaching method for light REEs}

dissolve apatite prior to the acid digestion stage. In this method, the leach residue from the first stage is digested in the second stage.

\section{Acknowledgments}

The authors wish to acknowledge the contribution by Professor J. Petersen and Dr M. Becker, Department of Chemical Engineering at the University of Cape Town, to the mineralogical work and for critical input to this paper.

\section{References}

AbHilash, S.S., Meshram, P., and PAndey, B.D. 2016. Metallurgical processes for the recovery and recycling of lanthanum from various resources-a review. Hydrometallurgy, vol. 160. pp. 47-59.

BANDARA, A.M.T.S. and SENANAyAKE, G. 2015. Leachability of rare-earth, calcium and minor metal ions from natural fluorapatite in perchloric, hydrochloric, nitric and phosphoric acid solutions: effect of proton activity and anion participation. Hydrometallurgy, vol. 153. pp. 179-189.

Binnemans, K., Jones, P.T., Blanpain, B., Van Gerven, T., and Pontikes, Y. 2015. Towards zero-waste valorisation of rare-earth-containing industrial process residues: a critical review. Journal of Cleaner Production, vol. 99. pp. 17-38.

Bonyadi, Z., Davidson, G.J., Mehrabi, B., Mefrre, S., and Ghazban, F. 2011. Significance of apatite REE depletion and monazite inclusions in the brecciated Se-Chahun iron oxide-apatite deposit, Bafq district, Iran: insights from paragenesis and geochemistry. Chemical Geology, vol. 281, no. 3. pp. 253-269.

Booomeri, M. 2011. Rare earth minerals in Esfordi magnetite-apatite ore deposit, Bafgh district. Iranian Journal of Geosciences, vol. 85, no. 22 pp. 71-82.

BOOMERI, M., NAKASHIMA, K., and LENTZ. D.R. 2009. RE minerals in Esfordi apatite-magnetite deposit, Central Iran. Proceedings of the 24th International Applied Geochemistry Symposium, Fredericton, New Brunswick, Canada, 1-4 June 2009.

HABASHI, F. 1985. The recovery of the lanthanides from phosphate rock. Journal of Chemical Technology and Biotechnology. Chemical Technology, vol. 35, no. 1. pp. 5-14.
Jha, M.K., Kumari, A., Panda, R., Kumar, J.R., Yoo, K., and Lee, J.Y. 2016. Review on hydrometallurgical recovery of rare earth metals. Hydrometallurgy, vol. 165, no. 1. pp. 2-26.

Jordens, A., Cheng, Y.P., and WATERS, K.E. 2013. A review of the beneficiation of rare earth element bearing minerals. Minerals Engineering, vol. 41. pp. 97-114.

Jorjani, E., Bagherieh, A.H., and Chelgani, S.C. 2011. Rare earth elements leaching from Chadormalu apatite concentrate: Laboratory studies and regression predictions. Korean Journal of Chemical Engineering, vol. 28, no. 2. pp. 557-562.

KHAWASSEK, Y., EliwA, A., GAWAD, E., and ABDo, S. 2015. Recovery of rare earth elements from El-Sela effluent solutions. Journal of Radiation Research and Applied Sciences, vol. 8, no. 4. pp. 583-589.

Krishnamurthy, N. and Gupta, C.K. 2004. Extractive Metallurgy of Rare Earths CRC Press.

LI, H., NA, Z., Zhang, G., Liu, Y., Long, Z., and HuAng, X. 2009. A process of smelting monazite rare earth ore rich in iron. Australian patent AU2008286599B2.

Moldoveanu, G.A. and Papangelakis, V.G. 2012. Recovery of rare earth elements adsorbed on clay minerals: I. Desorption mechanism. Hydrometallurgy, vol. 117-118. pp. 71-78.

SANDSTRÖM, A. and FREDRIKSSON, A. 2012. Apatite for extraction - leaching of Kiirunavaara apatite for simoltaneous production of fertilizers and REE. Proceedings of the 26th International Mineral Processing Congress (IMPC 2012), New Delhi, India, 24-28 September 2012. Technowrites. p. 476.

Stone, K., Bandara, A.M.T.S., Senanayake, G., and JayaseKera, S. 2016. Processing of rare earth phosphate concentrates: A comparative study of pre-leaching with perchloric, hydrochloric, nitric and phosphoric acids and deportment of minor/major elements. Hydrometallurgy, vol. 163. pp. $137-147$.

WANG, L., Long, Z., HuAng, X., Yu, Y., CuI, D., and Zhang, G. 2010. Recovery of rare earths from wet-process phosphoric acid. Hydrometallurgy, vol. 101, no. 1. pp. 41-47.

Wikipedia. 2016. Iron(III) phosphate. https://en.wikipedia.org/wiki//ron(III) phosphate [accessed October 2016].

ZHANHENG, C. 2011. Global rare earth resources and scenarios of future rare earth industry. Journal of Rare Earths, vol. 29, no. 1. pp. 1-6. 